\title{
Determining the Differences Between Academic Success and Perception Levels of Conservatory Students
}

\author{
Serkan OTACIOĞLU1
}

\begin{tabular}{l} 
ARTICLE INFO \\
\hline Article History: \\
Received 19.04.2016 \\
Received in revised form \\
01.06 .2016 \\
Accepted \\
Available online 20.06 .2016
\end{tabular}

\begin{abstract}
This research was studied about professionals in the field of music education students, with musical perception levels and some variable to reveal the differences that occur in this dimension. 50 students from Mimar Sinan University State Conservatory, 39 students from İstanbul University State Conservatory and 38 students from Karadeniz Technique University State Conservatory $(\mathrm{N}=127)$. Conservatory students, who are the students of the 2nd, 3 rd and 4th class in 2014-2015 academic year, have been participated which is a field research done by survey method.In this survey, two basic data collection tools were used. First data collection tool is "Student Information Form" which is aimed to obtain individual knowledge, second data collection tool is "Musical Perception Inventory" developed by G.Otacioğlu and Aslan in 2007 to measure musical perception skills of students. Statistical analysis techniques were used to demonstrate the differences between the variables in the study. As a result of the study, there were statistically significant differences between demographic variables and the scores of musical perception@ ${ }^{\circ}$ 2016IJERE. All rights reserved
\end{abstract}

Keywords:

Perception, musical perception, professional music education

\section{INTRODUCTION}

Music brings movement to the emotional and intellectual life of human as being an individual. Music education is one of the most important effective instruments for developing creative personality which especially important to consist a well-qualified society (Bilen, 1995:8).

When considering music individually, it is known that music is a necessary element for healthy individual development. Music education plays an important role for personality development which could keep up the faster change of world due to including dynamics inside (Şeker, 2011: 1).

Reading musical note and playing an instrument of a musician is process which requires many years. Additionally these acts are body-psychomotor skills which include too complicated processes in brain. It is required to use essential elements of music, fast and effective perception and transforming these perceptions to visual-motor system during playing music (Çuhadar, 2008).

It is aimed to train professional artists who will service for chamber music playing with voice education, soloist and instrument and sound educational fields in State Conservatory which services for one of main music education type: Occupational education institution. In Turkey State conservatories are organizations which aim to train artists and music trainers in accordance with the necessities of State Symphony Orchestra, state Opera and Ballets by providing the classical western music. According to "Higher Education Catalogue 2010" electronic catalogue, there are 26 pcs State Conservatories which provides western music education, 4 pcs Foundation University music department or performing arts faculty in our country. In conservatories which are divided into Performing arts department, music department and musicology departments, performing arts; opera, Ballet and theater art majors; music department provides wind instruments, percussion instruments, strings, piano, composition and conductorship, jazz educations. Accordingly conservatories aim to train artists for State Opera and ballet and State Symphony orchestra by providing to educate music, opera and ballet artists which our country requires (Eskioğlu, 2010).

\footnotetext{
1 Marmara University, Ataturk Education Faculty, Music Education Section.İstanbul/Turkey.Email: sotacioglu@marmara.edu.tr
} 
While the education is provided with block lessons, instrument and singing lessons are provided individually in these organizations which have been founded in order to train artists. It could be avowable to say that individual lessons are the most important lessons which affect the education quality of conservatory. Qualify of trainer is more important comparing to other education fields for individual educations due to these lessons are provided privately such as one trainer and one student. Role of trainer could be liken to a life coach and relationship of trainer and student could be liken to master- apprentice relationship in conservatory education.How the students who are educated as the above mentioned music system perceive themselves in musical aspects has been come to the fore (YOK, 15/10/2008).

Describing music perception as a physic-psychological phenomenon which consists of a range of audio system will not be sufficient. In order to explain this phenomenon emotions and thoughts which were loaded in to the music sounds and convenience of performance of these music sounds with music art should be revealed. A music piece is a musical message which was created by composer. Composer is the person who transmits the emotions received from the natural and social environment oriented from intellectual structure and psychological structure where they have been perceived by his/her personal abilities to his/her environment by loading them into the melodies. Commentator is the person who carries musical message of composer to the environment and listeners. There should be association with composer's esthetical artistic life and commentator's artistic life in order to carry the perceptions of composer which belongs to composer by holism (G. Otacıŏglu, 2008).

As long as this association grows the perception of composer and transmission ratio of commentator increases. For that reason there should be a common artistic - esthetical life fields which could associate composer and commentator in order to perceive the music message perception. In this situation in order to symmetric coincidence there should be a large ratio of composer, commentator and listener esthetical life field coincidence for the perceptions which listener received from melody. In order to transmit the musical messages sourced from composer to the individual and gradually to the society individuals should have a good musical education. So each individual who get trained should be as equipped as to interpret the composers and each type of musical pieces also they should teach these information and abilities to the others (Otacioğlu and Aslan, 2007).

It is significantly important how individuals who have been received music education alongside music ability perceive themselves in terms of music for their occupational development. An individual who considers himself/herself competent in this field could waver against the occupational difficulties after the music education. Realizing the deficiencies of individual depends how to know himself/herself and perception. So he/she could be a good musician and trainer by the time.

Modern education methods should be utilized in order to train an instrument or voice teacher in addition this education should be systematic, conscious and planned activity. In order to reach the success of teaching, activity should be tested and education programs in teaching faculties should be enhanced by research feedbacks. Measuring the musical perception ability which is one of the variables of success of teacher candidates and occupational education effectiveness consist the essential purposes of this research.

Answers were sought for below research questions in consideration of above mentioned information: Conservatory students who get professional instrument education: Is there a meaningful relationship between music perception and academic success? And is there a meaningful relationship between the variables of university and individual instruments? 


\section{METHOD}

\subsection{Research Model}

This research has been carried out by survey method. General scanning model is a research approach which describes a previous or current situation as it exists.

\subsection{Universe and sample}

Universe of research consist of the professional music education receiver license students who are educated different conservatories of Turkey. Sample of research consist of 127 students who were chosen randomly from the above mentioned universe. Demographical characteristics of music teacher candidate sample have been provided below (Table 1). Mimar Sinan University State conservatory $(\mathrm{n}=50)$, İstanbul University State conservatory $(n=39)$ and Karadeniz Technical University State conservatory $(n=38)$. Post graduate $3^{\text {rd }}$ and $4^{\text {th }}$ class 127 student educated in 2014-2015 education - term.

Table 1. Frequencyand percentage distributionsforthedemographic characteristics ofstudents

\begin{tabular}{cllc}
\hline Variable & Group & f & \% \\
\hline \multirow{2}{*}{ University } & Mimar Sinan & 50 & 11,6 \\
& İstanbul & 39 & 8,2 \\
& Karadeniz T.U. & 38 & 10,2 \\
\hline \multirow{2}{*}{ Gender } & Girl & 82 & 61,2 \\
& Boy & 45 & 38,8 \\
\hline \multirow{2}{*}{ Age } & $19-22$ & 69 & 70,2 \\
& $23-26$ & 32 & 23,8 \\
& $27-30$ & 26 & 6,0 \\
\hline \multirow{2}{*}{ Class } & $3^{\text {rd }}$ class & 65 & 50,6 \\
& $4^{\text {th }}$ class & 62 & 49,4 \\
\hline \multirow{2}{*}{ Instrument } & Strings & 52 & 54,1 \\
& Guitar & 34 & 16,0 \\
& Woodwind & 22 & 14,9 \\
& Voice & 13 & 6,0 \\
\hline
\end{tabular}

\subsection{Data collection instruments}

A duplex survey aimed at determining the relationship of students between demographical variables and musical perception levels was used. These sections are; personal information form in order to research the demographical characteristics of students, Musical perception scale.

\subsubsection{Personal Information Form}

This form includes 10 questions in order to collect the information of music education teacher candidates' demographical situation also university of students, gender, age, class, individual instrument, 
situation how individual consider himself/herself with regards to successful. Questions considered necessary were used in the research.

\subsubsection{Musical Perception Scale}

Three sub segment scale of Otacioğlu \& Aslan (2005) which was developed in order to determine the musical perception level of student has been used after receiving his permission accordingly the purpose of research in the second chapter of survey. After the confidentiality analyses of 97 questions of scale which was developed by Otacioğlu\&Aslan, Cronbach Apha coefficient related the sub-dimension of "General Music information and culture" was found 0,914; confidence coefficient sub-dimension of "technical and theoretic information" was found 0,960; confidence coefficient sub-dimension of "interest towards the music and attitude" was found 0,880. A fivefold option (Likert type) which determines the expression level of student for the related subject between "completely sufficient" (1) and "completely insufficient" (5) across the expressions of sub-dimensions. Validity and confidentiality of sub dimensions of scale has been tested by material analyze which was carried out accordingly purpose of research.

Alpha model and harmony values depending between the materials were calculated for confidentiality analyses of used scale and sub dimension materials. Depending on Alpha $(\alpha)$ coefficient scale and confidentiality of sub dimensions has been evaluated below. As seen on the table coefficient of sub dimension of musical perception scale was found between $\alpha=0,934$ and $\alpha=0,969$. That shows us musical perception sub dimensions and materials of sub dimensions have a strong relationship and their confidentiality is higher (internal consistency). As a result validity and confidentiality of scale has been considered higher and it could be used as is.

\subsection{Analyze for Data}

All the data collected from the participating students by survey (Personal Information Form, Musical Perception Scale) have been subjected to statistical analyze. Accordingly the purpose of research respectively frequency $(f)$ and percentage (\%) have been calculated; musical perception sub dimension level of students and average points $(\bar{X})$ of perception levels included in sub dimensions and standard deviations (ss) values have been calculated, depending on the demographical characteristics of students, accordingly the normality distribution of Musical Perception Scale Sub dimensions points, independent group t-test which used for comparing the double groups or Mann-Whitney Test (when normality assumption was not provided) and one way analyze of variance (Anova) or Kruskal-Wallis test (when normality assumption was not provided) which is used to compare three or more group comparison was applied. Post-Hoc LSD test was carried out when meaningful difference was found in one way analyze of variance in order to research where the difference exists between the groups.

\section{FINDINGS}

General findings related the musical perception level of students was placed in this subdivision of research. Students considered related option and points while assessing three dimensional musical perception scale materials such as "General Music Information", "Technical And theoretical information" and "interest and Attitude towards the music". General average points of participated student's related Musical Perception Scale sub dimensions have been calculated, have been given below table 2 .

Table 2: The averagescoresforthestudentsMusical PerceptionScalesubscales

\begin{tabular}{lcc}
\hline \multicolumn{1}{c}{ Factor } & $\bar{X}$ & ss \\
\hline $\begin{array}{l}\text { General/Music } \quad \text { Informationand } \\
\text { Culture }\end{array}$ & 3,24 & 0,58 \\
Technical\&theoretical knowledge & 3,40 & 0,64 \\
$\quad$ Interest and attitudes & 3,60 & 0,73 \\
\hline
\end{tabular}


As seen over the table dimension where students find themselves as most sufficient is interest and

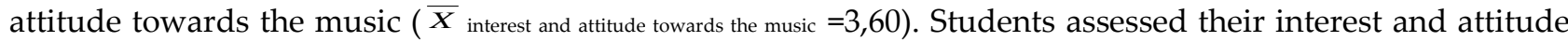
towards the music as "quite sufficient" level. In respect to other two dimensions, students assessed themselves as "slightly sufficient". The lowest average point was found for general musical information and

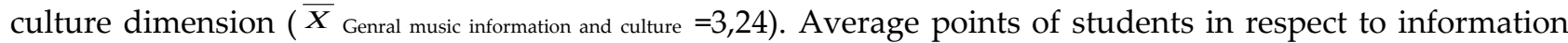
related technical and theoretical was "slightly sufficient" and it is a little bit higher than General Music information and culture $(\bar{X}$ Technical and theoretical information $=3,40)$.

Assessing the perception levels of students related musical perception scare according to demographical features. In this chapter whether students who participated the research have meaningful differentiation in perception levels related musical perception scale dimensions accordingly demographical features or not has been assessed. Comparing which was carried out according to university, gender, age, class, individual instrument of students was given in Table 3.

Tablo 3: Students Musical Perception Scale subscales of perception levels for showing that differentiation based on the university they studied variables Anova test

\begin{tabular}{|c|c|c|c|c|c|c|}
\hline \multirow[t]{2}{*}{ Factor } & \multirow[t]{2}{*}{ University } & \multicolumn{4}{|c|}{ Descriptive Statistics } & \multirow{2}{*}{$\frac{\text { Anova }}{p}$} \\
\hline & & $\mathbf{N}$ & $\overline{\bar{X}}$ & ss & F & \\
\hline \multirow{3}{*}{ GeneralMusic Informationand Culture } & Mimar Sinan & 50 & 3,10 & 0,58 & 5,65 & 0,041 \\
\hline & İstanbul & 39 & 3,26 & 0,61 & & \\
\hline & Karadeniz Teknik & 38 & 3,26 & 0,52 & & \\
\hline \multirow{3}{*}{ Technical and theoretical knowledge } & İstanbul & 39 & 3,25 & 0,65 & 6,87 & 0,028 \\
\hline & Karadeniz Teknik & 38 & 3,30 & 0,64 & & \\
\hline & Mimar Sinan & 50 & 3,49 & 0,56 & & \\
\hline \multirow{3}{*}{ Interest and attitudes } & Karadeniz Teknik & 38 & 3,40 & 0,85 & 9,29 & 0,012 \\
\hline & Mimar Sinan & 50 & 3,46 & 0,70 & & \\
\hline & İstanbul & 39 & 3,84 & 0,59 & & \\
\hline
\end{tabular}

Whether Musical perception scale sub dimensions perception levels of students significantly differ depending their university or not was assessed by Anova test and university variable cause significant differentiation in respect to three sub dimension was founded. General music information and culture perception level of students was found significantly different depending their university ( $\mathrm{F}=5,65$ and $\mathrm{p}<0,05)$. According to post-hoc LSD test results which were carried out to determine sub dimension was perceived different for which university students:

- Mimar Sinan University students and İstanbul and Karadeniz Technical University students' general music information and culture levels are different and this difference is against Mimar Sinan University students.

- Istanbul university students and Karadeniz Technical University and Mimar Sinan University student's technical and theoretical information levels are different and this difference is against İstanbul university students.

Finally it has been founded that interest and attitude towards the music of students has been found significantly different depending on their universities. According to the results of post-hoc LSD test which was carried out after Anova Test, interest and attitude towards the music of Karadeniz University students and Mimar Sinan University students are different and this difference is against the students of Karadeniz University. 
Whether Musical perception scale sub dimensions perception levels of students significantly differ depending their individual instruments or not was assessed by Anova test and individual interest variable did not because significant differentiation in respect to any sub dimension was founded in Table 4 .

Table 4: Students Musical Perception Scale subscales of perception levels for showing that differentiation based on the individual instrument variables Anova test

\begin{tabular}{|c|c|c|c|c|c|c|c|}
\hline \multicolumn{2}{|r|}{ Factors } & \multirow[t]{2}{*}{ Instruments } & \multicolumn{4}{|c|}{ Descriptive statistics } & \multirow{2}{*}{$\begin{array}{l}\text { Anova } \\
\mathrm{p}\end{array}$} \\
\hline & & & $\mathbf{N}$ & $\overline{\bar{X}}$ & ss & F & \\
\hline \multirow{5}{*}{$\begin{array}{l}\text { GeneralMusic } \\
\text { Culture }\end{array}$} & \multirow{5}{*}{ Informationand } & strings & 52 & 3,20 & 0,60 & 0,94 & 0,441 \\
\hline & & Guitar & 34 & 3,23 & 0,50 & & \\
\hline & & wind & 22 & 3,27 & 0,57 & & \\
\hline & & voice & 13 & 3,41 & 0,52 & & \\
\hline & & Piano & 6 & 3,26 & 0,47 & & \\
\hline \multirow{5}{*}{$\begin{array}{l}\text { Technical } \\
\text { knowledge }\end{array}$} & \multirow{5}{*}{ and theoretical } & strings & 52 & 3,41 & 0,64 & 0,48 & 0,750 \\
\hline & & guitar & 34 & 3,36 & 0,64 & & \\
\hline & & wind & 22 & 3,38 & 0.69 & & \\
\hline & & voice & 13 & 3,43 & 0,56 & & \\
\hline & & piano & 6 & 3,33 & 0,48 & & \\
\hline \multirow{5}{*}{\multicolumn{2}{|c|}{ Interest and Attitudes }} & strings & 52 & 3,62 & 0,75 & 0,30 & 0,876 \\
\hline & & guitar & 34 & 3,56 & 0,67 & & \\
\hline & & wind & 22 & 3,57 & 0,80 & & \\
\hline & & voice & 13 & 3,61 & 0,57 & & \\
\hline & & Piano & 6 & 3,55 & 0,65 & & \\
\hline
\end{tabular}

When assessing average points related sub dimensions of having different individual instrument students, it is seen that there are small differences.

Coefficients belonging to Pearson moments multiplying correlation which was carried out in order to assess the relationship between musical perception levels and individual instrument success levels of students who have participate the research were submitted in Table 5.

Table 5: Results for Relationships between Perception Levels with Academic Success of Students

Pearson results carried out for relation between "Musical perception and "Academic success" grades.

\begin{tabular}{lccccc}
\hline Measurement & $\mathbf{n}$ & $\bar{X}$ & sd & r & P \\
\hline M. Perception & 127 & 58.44 & 14.65 & \multirow{2}{*}{.055} & $.003^{*}$ \\
\cline { 2 - 4 } Academic Success & 127 & 67.27 & 21.55 & & \\
\hline
\end{tabular}

${ }^{*} p<.01$

It was determined that there was negative relation between "musical perception" and "academic success levels" in Table 5. When specifications of inventories we have considered, while grades received from musical perception was positive. "Higher" Grades received from academic success level was positive. 


\section{Conclusion and Discussion}

A number of researchers have been interested in the degree to which music aptitude or music experiences are related to academic achievement. The literature is nearly evenly divided between those studies in which a high degree of relationship was reported and those in which a low or negligent relationship was found. Using data from first and fourth graders, Lamar (1989) found a significant, positive relationship between music aptitude and reading and one that approached significance for math. Music aptitude was also highly related with academic achievement in eight to 12-year-old students (Johnson, 2000). Palos-Tuley (2003) found positive significant effects for academic achievement and the degree of involvement in the fine arts of Hispanic students in grades three, four, and five, involved in either: an intensive fine arts academy, a rotational fine arts program, or a minimal fine arts program.

Austin and Vispoel (2014) made a research called "How American Adolescents Interpret Success and Failure in Classroom Music: Relationships among Attributional Beliefs, Self-Concept and Achievement" Research involving early adolescents highlights systematic declines in motiva- tion for learning as students progress from elementary school to secondary school. Students' attributions or explanations for past achievement outcomes often are important determinants of future activity choice, investment and persistence. In this article, we critique prior music attribution research and report findings from our empirical study of American 7th-graders' attributional beliefs about success and failure in classroom music. Our results demonstrated that secondary students do not attribute success and failure to the same factors, and that many of the most salient reasons for music-related outcomes (family-, teacher- and peer-influence) are not addressed in traditional attribution research. Attributional beliefs, particularly those concerning music ability, were strongly linked to students' music self-concept and achievement test scores, and the magnitude of those linkages was typically greater when students reflected upon past failures. Based on these findings, we recommend that music practitioners increase their awareness of students' attributional beliefs (particularly the tendency to attribute failure to lack of ability and/or negative family influence), encourage students to consider the r6le that less stable and more controllable factors (effort, persistence, strategy use, metacognition) play in determining achievement outcomes, and employ instructional or evaluative strategies that promote more expansive and developmental views of music ability among all students.

Giomi (2004), in his study of the effects of three years of piano instruction is based on a sample of 117 fourth-grade children attending public schools in Montreal. The children had never participated in formal music instruction, did not have a piano at home, and their annual family income was below. Children in the experimental group $(n=63)$ received individual piano lessons weekly for three years and were given an acoustic piano at no cost to their families. Participants were administered tests of self-esteem, academic achievement, cognitive abilities, musical abilities, and motor proficiency at the beginning of the project and throughout the three years of piano instruction. The results indicated that piano instruction had a positive effect on children's self-esteem, perception and school music marks. It shows the importance of the relations between academic success and perception as this research.

Corrigal and friends (2013), although most studies that examined associations between music training and cognitive abilities had correlational designs, the prevailing bias is that music training causes improvements in cognition. It is also possible, however, that high-functioning children are more likely than other children to take music lessons, and that they also differ in personality. We asked whether individual differences in cognition and personality predict who takes music lessons and for how long. The participants were 118 adults (Study 1) and 167 10- to 12-year-old children (Study 2). We collected demographic information and measured cognitive ability and the Big Five personality dimensions. As in previous research, cognitive ability was associated with musical involvement even when demographic variables were controlled statistically. Novel findings indicated that personality was associated with musical involvement when demographics and cognitive ability were held constant, and that openness-to-experience was the personality dimension with the best predictive power. These findings reveal that: (1) individual differences influence who takes music lessons and for how long, (2) personality variables are at least as good as cognitive variables at predicting music training, and (3) future correlational studies of links between music training and non-musical ability should account for individual differences in personality. 
Harrison and friends(1994) found that, a latent-trait model describing the influence of musical aptitude, academic ability, music experience, and motivation for music on the development of aural skills by 142 music theory students was evaluated. The model accounted for $73 \%$ of the total aural skills variance, with the ear-training and sight-singing components variance being accounted for by the model at $79 \%$ and $44 \%$, respectively. Musical aptitude had the largest effect on performance in the aural skills components of the theory course, and the effects of academic ability and music experience were also statistically significant. Motivation for music did not affect aural skills performance, and it did not correlate significantly with any of the other latent variables like musical perception. It also shows parallel findings like this research.

As we see, in all areas of music, musical perception effects all areas of academic achievement, abilities, self-esteem in music education and individual motivation. In future research's like this can be made by large amount of students in different schools and ages.

\section{REFERENCES}

Austin, J. \& Vispoel, W. (2014).Psychology of Music, April 1998, vol. 26. no. 1, 26-45.

Bilen, S. (1995). İşbirlikli öğrenmenin müzik öğretimi ve güdüsel süreçler üzerindeki etkileri. Yayımlanmamış Doktora Tezi, D.E.Ü Eğitim Bilimleri Enstitüsü, İzmir.

Corrigall, K. E., Schellenberg, G., Misura, N. (2013). Music training, cognition, and personality. Frontiers in Psychology. April 2013.

Çuhadar, H.(2008). Müzik ve Beyin. Ç.Ü. Sosyal Bilimler Enstitüsü Dergisi, Cilt 17, Sayı 2, 2008, s.67-76. Eskioğlu, I. (2010). YÖK'ün lisansüstü program açma ölçütleri hakkında analitik tartışmalar ve müzik eğitimi alanı örneği. International Conference on New Trends in Education and Their Implications, 11-13 November, 2010 Antalya-Turkey.

Giomi-Costa,E.(2004). Effects of three years of piano instruction on children's academic achievement, school performance and self-esteem. Psychology of Music, vol. 32no. 2, 139-152. Harrison, C. Asmus, E and Serpe, R. (1994). Effects of musical aptitude, academic ability, music experience, and motivation on aural skills. Journal of Research in Music Education, vol. 42 no. 131-144.

Karasar, N. (2005). Bilimsel Arastırma Yöntemi.15. Basım Nobel Yayın Dagıtım, Ankara.

Johnson, D. A. (2000). The development of music aptitude and effects on scholastic achievement of 8 to 12 year olds. (Doctoral dissertation, University of Louisville). Dissertation Abstracts International, 61 (08), 3098A.

Lamar, H. B. (1989). An examination of the congruency of music aptitude scores and mathematics and reading achievement scores of elementary children. (Doctoral dissertation, The University of Southern Mississippi). Dissertation Abstracts International, 51 (03), 0778A.

Otacıoğlu, G. S. \& Aslan, E.(2007). Measurement of musical perception.The teacher and the Teaching Profession: Current Research and International Issues, Edited by Marina-Stefania Giannakaki, 157-171. Pub. Atiner.

Otacıoğlu, G. S. (2008). Psychology of Music. Öğreti Pub.Co.Ankara.

Öztopalan, E. (2007). İlköğretim düzeyindeki özel okullar ile devlet okullarının 6, 7 ve 8. sinı öğrencilerinin müzik dersine ilişkin tutumları ve akademik başarıları arasındaki ilişki. Yayınlanmamış Yüksek 
Lisans Tezi, Dokuz Eylül Üniversitesi Eğitim Bilimleri Enstitüsü.

Palos-Tuley, B. (2003). An examination of the relationship between fine arts experiences and creative thinking, academic self-concept, and academic achievement of Hispanic students in grades 3, 4, and 5 in selected south Texas schools. (Doctoral dissertation, Texas A \& M University). Dissertation Abstracts International, 65 (01), 008A.

Say, A. (2002). Türkiye'de cumhuriyet döneminde çağdaş müzik. v. türk kültürü kongresi, cumhuriyetten günümüze türk kültürünün dünü, bugünü ve geleceği. (17-21.12.2002) Atatürk Kültür Merkezi Başkanlığı, Ankara.

Şeker, S. (2011). 9-11 Yaş grubu çocuklarda orffschulwerk destekli keman eğitiminin keman dersine iliş̧in tutum, öz yeterlik, öz güven ve keman çalma becerisi üzerindeki etkileri. Yayınlanmamış Doktora Tezi. Dokuz Eylül Üniversitesi Eğitim Bilimleri Enstitüsü, İzmir

Uçan, A. (1994). Müzik eğitimi temel kavramlar-ilkeler-yaklaşımlar. Ankara: Müzik Ansiklopedisi Yayınları Uçan, A. (2005). İnsan ve müzik. insan ve sanat eğitimi. (3rd ed.). Ankara: Evrensel Müzikevi.

YÖK. (15/10/2008a) Lisansüstü eğitim ve öğretim yönetmeliği. (mad. 1 / a, b) Resmi Gazete Tarihi: 01.07.1996 Resmi Gazete Sayıs1: 22683: mad. 2 / a, b, c, mad.9/ a, mad.14 a, mad. 18 a, b mad. 26 a 